\title{
UPAYA MENINGKATKAN HASIL BELAJAR IPS DENGAN METODE DISKUSI MENGGUNAKAN MEDIA GAMBAR DI KELAS VII-3 SMP NEGERI 2 PALANGKA RAYA
}

\author{
Oleh \\ Salya Marshanda, * Santi Endriani** \\ Email: santiendriyani@yahoo.com
}

\begin{abstract}
This study aims to determine the learning activities of students and increase learning outcomes of social studies students. The method used in this study was to use the Classroom Action Research (CAR) design. The subjects needed in this study were students of class VII-3 of SMP Negeri 2 Palangka Raya, amounting to 29 students, for data collection techniques used observation and tests. While in this study using qualitative and quantitative data analysis. The results of the study show that: (1) Student learning activities are good. This is evidenced by the increase in the average score of learning activities of students in the first cycle obtaining an average score of 3.86 with the criteria of Good. (2) There is an increase in learning outcomes as evidenced by an increase in classical completeness from pre-action (pre-test), learning outcomes of students get an average score of 36.89 with completeness of $0 \%$ or no students complete or score $\leq 75$ and post test cycle I learning outcomes students get an average value of 80.51 with completeness $96.55 \%$ or get a value of $\geq 75$.
\end{abstract}

(C) Muhammadiyah University of Palangkaraya

Keywords: Social Studies Learning Outcomes, Discussion Methods, and Image Media

\begin{abstract}
ABSTRAK
Penelitian ini bertujuan untuk mengetahui aktivitas belajar peserta didik dan peningkatan hasil belajar IPS peserta didik. Metode yang digunakan dalam penelitian ini adalah menggunakan rancangan Penelitian Tindakan Kelas (PTK). Subjek yang dibutuhkan dalam penelitian ini adalah peserta didik kelas VII-3 SMP Negeri 2 Palangka Raya yang berjumlah 29 orang peserta didik, untuk teknik pengumpulan data digunakan observasi dan tes. Sedangkan dalam penelitian ini menggunakan analisis data kualitatif dan kuantitatif. Hasil penelitian menunjukan bahwa: (1) Aktivitas belajar peserta didik menjadi baik. Hal ini di buktikan dengan adanya peningkatan skor ratarata aktivitas belajar peserta didik pada siklus I memperoleh skor rata-rata 3,86 dengan kriteria Baik. (2) Ada peningkatan hasil belajar di buktikan dengan adanya peningkatan ketuntasan klasikal dari pra tindakan (pre test), hasil belajar peserta didik mendapatkan nilai rata-rata 36,89 dengan ketuntasan $0 \%$ atau tidak ada peserta didik yang tuntas atau mendapat nilai $\leq 75$ dan post test siklus I hasil belajar peserta didik mendapatkan nilai rata-rata 80,51 dengan ketuntasan $96,55 \%$ atau mendapatkan nilai $\geq 75$.
\end{abstract}

CUniversitas Muhammadiyah Palangkaraya

Kata Kunci: Hasil Belajar IPS, Metode Diskusi, dan Media Gambar.

Salya Marshanda* Mahasiswa FKIP UM Palangkaaraya

Santi Endriani** Dosen Universitas Muhammadiyah Palangkaraya 


\section{PENDAHULUAN}

Pendidikan merupakan salah satu sektor penting dalam pembangunan di setiap Negara. Pendidikan merupakan usaha sadar dan terencana untuk mengembangkan segala potensi yang dimiliki peserta didik melalui proses pembelajaran. Pendidikan bertujuan untuk mengembangkan potensi anak agar memiliki kekuatan spiritual keagamaan, pengendalian diri, berkepribadian, memiliki kecerdasan, berahlak mulia serta memiliki keterampilan yang diperlukan sebagai anggota masyarakat dan warga negara. Untuk mencapai tujuan pendidikan disusunlah kurikulum yang merupakan seperangkat rencana dan pengaturan mengenai tujuan, isi, bahan dan metode pembelajaran.

Suatu pendidikan dikatakan berkualitas apabila proses belajar berlangsung secara efektif dan peserta didik mengalami proses pembelajaran yang bermakna. Belajar bagi pelajar atau mahasiswa merupakan kata yang tidak asing. Bahkan sudah merupakan bagian yang tidak terpisahkan dari semua kegiatan mereka dalam menuntut ilmu di lembaga pendidikan. Perubahan yang terjadi pada seseorang banyak sekali baik sifat maupun jenisnya karena itu sudah tentu tidak setiap perubahan dalam diri seseorang merupakan perubahan dalam arti belajar.

Menurut Slameto (2010:3) belajar adalah suatu proses usaha yang dilakukan seseorang untuk memperoleh suatu perubahan tingkah laku yang secara keseluruhan sebagai hasil pengalamannya sendiri dalam interaksi dengan lingkungannya. Menurut Hamalik (2005:21) mendefinisikan belajar sebagai kegiatan-kegiatan fisik atau badaniah, merupakan suatu bentuk pertumbuhan atau peruri seseorang yang dinyatakan dalam cara-cara bertingkah laku yang baru berkat pengalaman dan pengetahuan.

Sugihartono, dkk (2007:74) mendefinisikan belajar dalam dua pengertian pertama, belajar sebagai proses memperoleh pengetahuan dan kedua, belajar sebagai perubahan kemampuan bereaksi yang relatif langgeng sebagai hasil latihan yang diperkuat. Definisi-definisi yang telah dikemukakan itu diberikan oleh para ahli yang berbeda pendiriannya serta berlainan titik tolaknya.

Dari definisi mengenai belajar di atas maka definisi belajar adalah perubahan tingkah laku yang dialami seseorang melalui panca indera sebagai hasil dan latihan-latihan. Menurut Slameto (2010:3) menyebutkan ada beberapa ciri-ciri danjenis-jenis belajar adalah sebagai berikut. Oleh karena itu, guna menunjang pendidikan yang berkualitas maka seluruh komponen pendidikan harus ikut terlibat. Proses belajar mengajar tidak terlepas dari peran serta seorang guru, dalam hal ini guru harus dapat mempersiapkan berbagai kebutuhan yang digunakan. Seorang guru harus dapat mengetahui karakteristik setiap peserta didik, sehingga guru dapat memberi materi 
pelajaran dengan baik dan peserta didik dapat memahami materi pelajaran yang diberikan oleh guru. Sebagai seorang tenaga pengajar sudah semestinya seorang guru senantiasa meningkatkan kualitas pembelajaran. Dengan memanfaatkan berbagai sarana dan prasarana yang ada khususnya media pembelajaran yang dapat meningkatkan pemahaman peserta didik dalam menerima materi pelajaran. Dalam memberikan materi pelajaran yang diberikan diharapkan guru dapat menggunakan berbagai media pembelajaran. Jika media yang dibutuhkan guru tidak tersedia maka guru dapat mengembangkan kreatifitasnya untuk membuat media pembelajaran yang dibutuhkan. Di masa yang akan datang peserta didik akan menghadapi tantangan berat karena kehidupan masyarakat global selalu mengalami perubahan setiap saat. Oleh karena itu mata pelajaran IPS dirancang untuk mengembangkan pengetahuan, pemahaman, dan kemampuan analisis terhadap kondisi sosial masyarakat dalam memasuki kehidupan bermasyarakat yang dinamis. Ilmu Pengetahuan Sosial (IPS) merupakan salah satu mata pelajaran yang mengkaji seperangkat peristiwa, fakta, konsep, dan generalisasi yang berkaitan dengan isu sosial. Pada jenjang SMP mata pelajaran IPS memuat materi Geografi, Sejarah, Sosiologi, dan Ekonomi. Melalui mata pelajaran IPS, peserta didik diarahkan untuk dapat menjadi warga negara Indonesia yang demokratis, dan bertanggung jawab, serta warga dunia yang cinta damai.Guru harus dapat berusaha merangsang peserta didik untuk dapat mengungkapkan pendapat melalui berbagai cara misalnya dengan menggunakan berbagai metode yang dapat membuat peserta didik mengungkapkan pendapat mereka salah satunya metode diskusi kelompok.

Penggunaan berbagai media pembelajaran merupakan syarat keberhasilan proses belajar. Berbeda dengan kenyataan di lapangan, pada proses pembelajaran di kelas VII-3 SMP NEGERI 2 PALANGKA RAYA, para peserta didik menganggap bahwa pelajaran IPS adalah pelajaran menghafal yang berisi ceramah guru. Penggunaan metode ceramah dirasa peneliti kurang merangsang peserta didik untuk dapat mengungkapkan pendapat mereka dan kurangnya media pembelajaran yang digunakan guru akan membuat peserta didik menjadi tidak tertarik dalam mengikuti proses pembelajaran. Menurut Sudjana dan Riva (Arsyad, 2005: 24) media akan membantu kelancaran, efisiensi dan efektivitas. Pembelajaran melalui media akan menjadikan peserta didik berlatih, bermain asyik dan bekerja dengan demikian media dapat membantu menghidupkan suasana kelasnya dan menghindari suasana monoton dan membosankan sehingga dapat menciptakan proses pembelajaran menjadi lebih menarik. Oleh karena itu, keterampilan manajerial pembelajaran guru harus senantiasa mewaspadai 
pembelajaran yang berorientasi pada media gambar.

Menurut Kemp dan Dyton (Arsyad, 2005: 19) Media merupakan salah satu komponen yang tidak bisa diabaikan dalam pengembangan sistem pengajaran yang sukses, dengan media dapat membantu guru dan peserta didik melakukan komunikasi dua arah secara aktif. Sejalan dengan perubahan pandangan tentang pengertian belajar mengajar, maka berubah pula pandangan tentang belajar mengajar, maka berubah pula pandangan tentang media. Media tidak lagi dipandang hanya sebagai alat bantu yang digunakan jika perlu tetapi media dapat membantu guru dalam menyalurkan pesan. Sehingga semakin baik media yang digunakan, semakin baik pula pesan yang diterima peserta didik. Dalam hal ini media akan membantu peserta didik dalam memahami pelajaran IPS. Dalam proses belajar mengajar kehadiran media cukup penting khususnya media gambar. Media gambar jika dibuat dan disajikan sesuai dengan persyaratan yang baik, sudah tentu akan menambah semangat peserta didik dalam mengikuti proses pembelajaran. Dengan gambar peserta didik termotivasi untuk belajar dan terus menerus belajar, sehingga rasa keingintahuan peserta didik besar dan mendorong peserta didik untuk selalu belajar.

Peserta didik menganggap pelajaran IPS sebagai suatu mata pelajaran yang tidak menarik sehingga peserta didik kurang aktif dalam mengikuti kegiatan belajar mengajar di kelas yang menyebabkan hasil belajar peserta didik dalam pembelajaran IPS tidak optimal. Hal ini terlihat dari hasil belajar peserta didik yang masih dibawah KKM, permasalahan ini yang dijadikan dasar dalam upaya meningkatkan hasil belajar peserta didik dengan metode diskusi berbantuan media gambar. Sehingga dengan penelitian ini diharapkan peserta didik Kelas VII-3 SMP NEGERI 2 PALANGKA RAYA, lebih tertarik dan termotivasi untuk belajar IPS sehingga prestasi belajar peserta didik meningkat.

Berdasarkan hasil observasi yang ditemukan oleh peneliti, dapat disampaikan hasil belajar ips peserta didik kelas VII-3 SMP Negeri 2 Palangka Raya masih belum mencapai nilai standar, sedangkan nilai ketuntasan minimum (KKM) 75. Jumlah dari peserta didik kelas VII-3 SMP Negeri 2 Palangka Raya 29 orang, yang mampu memenuhi perolehan nilai standar 10 orang atau $(34,48 \%)$ peserta didik, sedangkan 19 orang atau $(65,52 \%)$ peserta didiknya belum memenuhi nilai standar atau dibawah KKM.

Masih rendahnya hasil belajar IPS di sebabkan oleh adanya kemampuan menghapal daripada kemampuan memproses sendiri pemahaman suatu materi. Selama ini, minat belajar peserta didik terhadap mata pelajaran ips masih tergolong sangat rendah. Hal ini dapat dilihat dari sikap peserta didik selama mengikuti proses pembelajaran, ada yang ijin keluar masuk 
kelas di luar materi yang di ajarkan. Mata pelajaran IPS yang salah satu cabangnya mempelajari mengenai masalah sosial. Karena keterbatasan kemampuan orang untuk mendatangi berbagai tempat di muka bumi ini, maka dibuatlah suatu media pembelajaran yang dapat digunakan sebagai sarana belajar suatu tempat di muka bumi ini tanpa harus datang di tempat tersebut. Salah satu wujud media pembelajaran tersebut adalah gambar. Gambar ini dipilih sebagai sarana belajar IPS karena gambar merupakan gambaran konvensional dari permukaan bumi yang diperkecil, dengan menggunakan gambar ini kita dapat mempelajari suatu bentuk permukaan bumi tanpa harus mendatangi tempat tersebut. Berdasarkan gambaran diatas maka peneliti terdorong melakukan penelitian yang berjudul: Upaya Meningkatkan Hasil Belajar IPS Dengan Metode Diskusi Menggunakan Media Gambar di Kelas VII-3 SMP NEGERI 2 PALANGKA RAYA.

Berdasarkan rumusan masalah di atas maka tujuan tujuan ini adalah sebagai berikut:

1. Untuk mendeskripsikan aktivitas belajar IPS peserta didik Kelas VII-3 SMP Negeri 2 Palangka Raya dengan metode diskusi menggunakan media gambar.

2. Untuk meningkatkan hasil belajar IPS dengan metode diskusi menggunakan media gambar di Kelas VII-3 SMP Negeri 2 Palangka Raya dapat meningkatkan hasil belajar peserta didik

\section{METODE PENELITIAN}

Penelitian yang digunakan adalah penelitian tindakan kelas (classroom action research) yang dilakukan oleh peneliti secara langsung. Dimana penelitian tersebut langsung dalam penelitian sejak awal sampai dengan hasil penelitian berupa laporan. Dalam penelitian ini, peneliti bertindak sebagai peneliti dan pengajar.

Menerut Kunandar (2010:46), Penelitian tindakan kelas adalah suatu penelitian yang berbasis kepada kelas. Penelitian dapat dilakukan secara mandiri, tetapi alangkah baiknya dilaksanakan secara kolaboratif, baik dengan teman sejawat, kepala sekolah, pengawas, dosen dan pihak yang relevan dengan PTK.

Menurut Paizaludin dan Ermalinda (2016:7): Penelitian tindakan kelas adalah suatu kegiatan penelitian dengan mencermati sebuah kegiatan belajar yang di berikan tindakan, yang secara sengaja dimunculkan dalam sebuah kelas, yang bertujuan memecahkan masalah atau meningkatkan mutu pelajaran di kelas tersebut.

Dalam penelitian PTK ini yang digunakan adalah berkolaborasi dengan guru dimana secara keseluruhan peneliti ini mencakup kegiatan-kegiatan seperti:

1. Perencanaan, mencakup membuat rencana pembelajaran, membuat lembar observasi. 
2. Melakukan

tindakan, melaksanakan semua perenanaan yang telah disusun.

3. Pengamatan, melakukan pengamatan dengan mengisi lembar observasi.

4. Refleksi, kegiatan mengingat dan merenungkan kembali suatu tindakan yang berdasarkan catatan pengamatan.

\section{HASIL DAN PEMBAHASAN}

1. Aktivitas Peserta Didik

Perubahan aktivitas peserta didik pada siklus I menjadi lebih baik dalam pembelajaran IPS dengan materi tentang Kehidupan Pada Masa Pra Aksara di Indonesia dengan menerapkan Metode Diskusi Menggunakan Media Gambar. Berdasarkan pengamatan aktivitas belajar peserta didik selama pembelajaran siklus I diketahui adanya perubahan aktivitas dari siklus I diperoleh rata-rata 3,86. Artinya ada peningkatan aktivitas peserta didik pada saat di terapkannya Metode Diskusi Menggunakan Media Gambar. Peningkatan aktivitas peserta didik dapat di disimpulkan bahwa aktivitas guru pada Siklus I yaitu 3,7 dan aktivitas peserta didik pada Siklus I yaitu 3,86.

2. Peningkatan Hasil Belajar Peserta Didik

Hasil belajar peserta didik setelah Menerapkan Metode
Diskusi Menggunakan Media Gambar terjadi peningkatan. Dapat di ketahui bahwa hasil belajar peserta didik dari test awal (pre test) sampai dengan siklus I telah terjadi peningkatan, dari 29 peserta didik pada test awal (Pre test) jumlah peserta didik yang tuntas tidak ada dan pada siklus I ada 28 peserta didik yang tuntas. Jumlah peserta didik yang tidak tuntas pada test awal (pre test) ada 29 peserta didik dan siklus I yang tidak tuntas ada 1 peserta didik. Peningkatan hasil belajar klasikal dan nilai rata-rata kelas dari tahap pre test dan siklus I di atas, dapat di simpulkan bahwa nilai rata-rata hasil belajar peserta didik pada pra siklus (pre test) yaitu 38,45 dan nilai rata-rata hasil belajar peserta didik pada post test (siklus I) yaitu 80,51.

Adapun mengenai nilai ketuntasan klasikal hasilbelajar peserta didik dapat disimpulkan bahwa nilai ketuntasan klasikal hasil belajar peserta didik pada pra siklus (pre test) yaitu $0,00 \%$.sedangkan nilai ketuntasan klasikal hasil belajar peserta didik pada post test (siklus I) yaitu 96,55\% .

Berdasarkan rumusan masalah dan indikator yang dilakukan dalam penelitian ini, sesuai dengan data temuan hasil belajar analisis aktivitas dan peningkatan hasil belajar peserta didik setelah dilakukan perbaikan dengan menerapkan Metode Diskusi 
Menggunakan Media Gambar, terbukti dapat mencapai hasil yang lebih baik dari sebelumnya. Pada pelaksanaan peningkatan hasil belajar peserta didik dalam pembelajaran IPS ini terbukti telah terjadi peningkatan dari kondisi awal pre test yang tuntas tidak ada $(0 \%)$ dan post test (siklus I) yang tuntas 28 peserta didik $(96,55 \%)$.

\section{KESIMPULAN}

Berdasarkan hasil penelitian yang telah di bahas maka dapat di simpulkan sebagai berikut:

1. Aktivitas belajar peserta didik kelas VII-3 SMP Negeri 2 Palangka Raya dalam pembelajaran IPS dengan Menerapkan Metode Diskusi Menggunakan Media Gambar menjadi baik. Hal ini di buktikan dengan adanya peningkatan skor rata-rata aktivitas belajar peserta didik pada siklus I memperoleh skor rata-rata 3,86 dengan kriteria Baik.

2. Ada peningkatan hasil belajar IPS peserta didik kelas VII-3 SMP Negeri 2 Palangka Raya dengan menerapkan Metode Diskusi Menggunakan Media Gambar. Hal ini di buktikan dengan adanya peningkatan ketuntasan klasikal dari pra tindakan (pre test), hasil belajar peserta didik mendapatkan nilai rata-rata 38,45 dengan ketuntasan $0 \%$ atau tidak ada peserta didik yang tuntas atau mendapat nilai $\leq 75$ dan post test siklus I hasil belajar peserta didik mendapatkan nilai ratarata 80,51 dengan ketuntasan 96,55\% atau mendapatkan nilai $\geq 75$.

\section{DAFTAR PUSTAKA}

Arsyad Azhar. 2005. Media Pembelajaran. Jakarta: Raja Grafindo Persada

Arsyad Azhar. 2005. Media Pembelajaran. Jakarta: Raja Grafindo Persada

Kunandar, (2010) . Langkah Mudah Penelitian Tindakan Kelas Sebagai Pengembangan Profesi Guru Edisi Revisi. Jakarta: PT Raja Grafindo Persada

Oemar Hamalik. 2005. Kurikulum Pembelajaran. Jakarta: Bumi Aksara

Paizaludin dan Ermalinda. (2016). Penelitian Tindakan Kelas. Bandung: Alfabeta

Slameto. 2010. Belajar dan Faktorfaktor Yang Mempengaruhinya. Jakarta: Rineka Cipta

Sugihartono. 2007. Psikologi Pendidikan. Yogyakarta: Unypers 